\title{
The Social Good of a Sacramental Ecclesiology: De Lubac, Liberation Theology, and Progress ${ }^{1}$
}

\author{
James R. Wood, Wycliffe College
}

Abstract: Joseph Flipper has recently charged Henri de Lubac with a failure to extend notions of sacramental significance beyond the liturgical fellowship of the Church. This apparent restriction is displayed most prominently in de Lubac's reservations about liberation theology and programs of "progress." This article examines de Lubac's criticisms of - and convergences with - liberation theology, with a focus on the work of Gustavo Gutiérrez, who admits the influence of de Lubac on his own thought and offers a somewhat different version of a sacramental ecclesiology. I show that considering the sociopolitical and post-conciliar context of de Lubac's work can inform a proper understanding such differences and convergences. While de Lubac certainly maintains an ecclesial center in his political theology, he is clearly concerned about the pursuit of the social good beyond the Church. I conclude that the inconsistency perceived by Flipper is mitigated by these considerations, and by reading de Lubac's later comments on progress and liberation in the light of his earlier efforts in resisting anti-Semitism and racist nationalism.

Keywords: Ecclesiology, Joseph Flipper, Gustavo Gutiérrez, Liberation Theology, Henri de Lubac, Political Theology

$\mathrm{T}$ This paper addresses Joseph S. Flipper's recent challenges ${ }^{2}$ to the political theology of Henri de Lubac (1896-1991), which according to Flipper neglects to extend notions of sacramental significance beyond the liturgical fellowship of the Church into the broader social sphere. This limitation is perhaps most noticeable in de Lubac's reservations about liberation theology and notions of "progress," as expressed in his postconciliar writings. ${ }^{3}$ Flipper argues that de Lubac's failure to apply his

1. Paper presented on November 1st, 2019, for the Colloquium "Christian Theology After Christendom." Organized by McGill University's School of Religious Studies and University of Toronto's Emmanuel College.

2. Flipper's concerns are expressed in his book, Between Apocalypse and Eschaton: History and Eternity in Henri de Lubac (Minneapolis, MN: Fortress Press, 2015), which is a reworked version of his dissertation, "Sacrament and Eschatological Fulfillment in Henri de Lubac's Theology of History" (PhD diss., Marquette University, 2012). The arguments are echoed in a condensed form in his essay, "Henri de Lubac and Political Theology," in T\&T Clark Companion to Henri de Lubac, ed. Jordan Hillebert (New York: Bloomsbury T\&T Clark, 2017).

3. The phenomenon is most noticeable in A Brief Catechesis on Nature and Grace [Petite catéchèse sur nature et grâce], trans. Richard Arnandez (San Francisco: Ignatius Press, 1984 [1980]) but is also present in other postconciliar texts, including especially The Motherhood of the Church: Followed by Particular Churches in the Universal Church [La maternité de l'Église; Les églises particulières dans l'Église universelle], trans. Sr. Sergia Englund (San Francisco: Ignatius Press, 1982 [1971]) and La Postérité spirituelle de Joachim de Flore, 2 vols. (Paris: Lethielleux, 1978 and 1981). The author who has devoted most attention to this shift in emphasis in de Lubac's postconciliar writings is Christopher J. Walsh, for example in his "Henri de Lubac and the Ecclesiology of the Postconciliar Church: An Analysis of His Later Writings (19651991)" (PhD diss., CUA, 1993), and his "De Lubac's Critique of the Postconciliar Church," Communio 19 (Fall 1992): 404432. A similar dynamic is present in the writings of de Lubac's close friend, Hans Urs von Balthasar. See James R. Wood, "Leaven without Loss: Church and World across Balthasar's Corpus," Pro Ecclesia: A Journal of Catholic and Evangelical Theology 29, no. 3 (2020): 308-335. 
sacramental logic to broader contexts leads him into a version of the extrinsicism ${ }^{4}$ against which he battled for his entire theological career. ${ }^{5}$

For this study, the essential question is whether there are sufficient resources within de Lubac's sacramental ecclesiology to inspire and inform Christian social action in the world outside the Church (ecclesia ad extra). ${ }^{6}$ I therefore examine de Lubac's criticisms of and convergences with liberation theology, focusing on Gustavo Gutiérrez (b. 1928) - a leading figure influenced by de Lubac who offers a somewhat different version of a sacramental ecclesiology. I argue that de Lubac's concerns are best understood within their broader socio-political and postconciliar context, and I show that his ecclesial political theology is concerned about the social good beyond the borders of the Church, paying special attention to his earlier efforts in resisting anti-Semitism and racist nationalism. My cumulative argument is that bringing such considerations to bear effectively mitigates Flipper's charge of inconsistency.

\section{De Lubac's Sacramental Ecclesiology}

The Church is a central theme in de Lubac's theology, ${ }^{7}$ as the "existential center" of the entire mystery of salvation. ${ }^{8}$ Throughout his career, one of the predominant images employed by de Lubac to describe the Church is the "sacrament." A sacrament, according to de Lubac, is a sensible bond between

4. De Lubac followed Maurice Blondel (1861-1949) in rejecting the "two-storey" view of creation entailed by the neoscholastic scheme of "pure nature." Blondel coined the neologism "extrinsicism" to describe this ratification of a material separation between supernature and nature. For Blondel, this extrinsicism suggests that the orders of nature and redemption/grace are distinct and independent. De Lubac largely accepted Blondel's analysis and rejected this whole conceptual scheme throughout his career.

5. This study is in broad agreement with the recent work of Jordan Hillebert: Henri de Lubac and the Drama of Human Existence (Notre Dame, IN: Notre Dame, 2021). Hillebert provides a helpful corrective to some of the recent interpretations of de Lubac which posit a version of intrinsicism in his rejection of extrinsicism. Hillebert correctly, in this author's view, explains de Lubac's paradoxical understanding of the relation between nature and the supernatural/grace, and thus avoids both extrinsicism and intrinsicism. Humans are naturally ordered to a supernatural finality; only the supernatural enjoyment of God can satisfy the absolute longing of human beings. Yet, nature is not already graced; the desire is born of a lack and is not itself the beginnings of possession. See especially the "Introduction" and Chapter 2.

6. The formal distinction between ecclesia ad intra and ecclesia ad extra was introduced in the second half of the twentieth century. The former pertains to the internal life, structure, and practices of the Church, whereas the latter refers to the Church's engagement with the broader world in missions, social action, public pronouncements, etc. The distinction serves to highlight relative emphases and different perspectives through which to understand the nature of the Church and its role in the world. These different angles of approach can be recognized in the documents of the Second Vatican Council. The Dogmatic Constitution on the Church (Lumen Gentium, November 21, 1964) reflects primarily ad intra realities, whereas the Pastoral Constitution on the Church in the Modern World (Gaudium et Spes, December 7, 1965) is more focused on ad extra concerns. More documents oriented toward ecclesia ad intra would be the Constitution on the Sacred Liturgy (Sacrosanctum Concilium, December 4, 1965) and the Decree on Ecumenism (Unitatis Redintegratio, November 21, 1964), whereas documents such as the Declaration on the Relation of the Church to Non-Christian Religions (Nostra Aetate, October 28, 1965), the Declaration on Religious Freedom (Dignitatis Humanae, December 7, 1965), and the Decree on the Mission Activity of the Church (Ad Gentes, December 7, 1965) address issues more related to ecclesia ad extra. See Susan K. Wood, "Henri de Lubac and the Church-World Relationship in Gaudium et Spes," in The Legacy of Vatican II, ed. Massimo Faggioli and Andrea Vicini (New York: Paulist Press, 2015).

7. See the comment in John Milbank's introduction to the theology of Henri de Lubac, The Suspended Middle: Henri de Lubac and the Renewed Split in Modern Catholic Theology, 2nd ed. (Grand Rapids, MI: Eerdmans, 2014), 65. "[D]e Lubac's ecclesiology [...] is almost as central to his opus as is the surnaturel thematic." According to Walsh, the final twenty-six years of de Lubac's life - after the Council - were as active as any other period, and were particularly focused on contemporary ecclesiology. See Walsh, "De Lubac's Critique of the Postconciliar Church," 404.

8. Hans Urs von Balthasar, The Theology of Henri de Lubac (San Francisco: Ignatius Press, 1992), 107.

9. This is developed in many of his works, but most prominently in his early masterpiece Catholicism: Christ and the Common Destiny of Man [Catholicisme: les aspects sociaux du dogme], trans. Lancelot Sheppard and Elizabeth Englund (San Francisco: Ignatius, 1988 [1938]), as well as in two of his books most directly focused on ecclesiology: The Splendour of the Church [Méditation sur l'Église], trans. Michael Mason (San Francisco: Ignatius Press, 1986 [1953]) and The Church: Paradox and Mystery [Paradoxe et Mystère de l'Église], trans. James R. Dunne (Staten Island, NY: Alba House, 1969 [1967]). 
worlds, a divinely instituted instrument of mediation - uniting realities by making present what it evokes. ${ }^{10}$ The primary reality to which the Church as sacrament refers is Christ - for as Christ is the sacrament of God, so the Church is the sacrament of Christ. ${ }^{11}$ From this point of view, the Church is not a purely human institution which can be understood exclusively in sociological terms. Rather, it is constituted in relation to Christ and makes Christ present in the world. ${ }^{12}$ Made up of sinful people, the Church carries this "borrowed splendor in a shabby garment." ${ }^{13}$ It nevertheless carries the hope of the world, since the Church is the site of eschatological communion and instrument of divinization. ${ }^{14}$ The new situation between God and humanity - the salvation accomplished in Christ - awaits its full extension. The Church is a visible and historical anticipation of eschatological communion as well as a means to its completion. This anticipation is however always imperfect and incomplete, and so the Church must continually strive to be a better resemblance of the reality to which it bears witness and which constitutes its being.

\section{De Lubac's Emphatic Social Concern}

De Lubac's theological career could be characterized as a sustained effort to properly reunite various realities which had been separated in modernity: nature and grace, Church and sacrament, salvation and sociality, Christianity and society, etc. He, among others, helped retrieve the image of the Church "as sacrament" (as mentioned above), and he was the foremost theologian in the West in recovering a "eucharistic ecclesiology" that foregrounds the intrinsic interrelatedness of the sacrament and the social body of the Church. ${ }^{15}$ De Lubac developed his sacramental ecclesiology from properly theological concerns but also with a view toward conceptualizing the role of the Church in the modern world. Working from within "secular" France (i.e., the arrangement labeled laïcité resulting from the 1905 law of separation, which itself was the culmination of a century of secularizing developments in France), he labored to reconnect Christianity and society in the modern world ${ }^{16}$ - calling into question the very categories which led to their separation. His sacramental ecclesiology was key in that effort.

Across de Lubac's works, he consistently wrote against the extremely individualistic and privatized religious sensibility of his day by emphasizing the social nature of salvation, the sacraments, and the Church. ${ }^{17}$ Furthermore, he claimed that there is no restriction on the Church's concerns. Salvation pertains

10. See de Lubac, Splendor of the Church, $202 \mathrm{f}$.

11. See de Lubac, Catholicism, 76; Paradox and Mystery, 14, 23ff.

12. See de Lubac, Catholicism, 73, 196; Splendor, 203f; Paradox and Mystery, 26, 53ff; Corpus Mysticum: The Eucharist and the Church in the Middle Ages [Corpus Mysticum: Essai sur L'Eucharistie et l'Église au moyen âge], trans. Gemma Simmonds, Richard Price, and Christopher Stevens; ed. Laurence Hemming and Susan Frank Parsons (South Bend, IN: Notre Dame, 2007 [1944]), 45ff.

13. De Lubac, Paradox and Mystery, 23ff. See also Dennis M. Doyle, "Henri de Lubac and the Roots of Communion Ecclesiology," Theological Studies 60, no. 2 (1999): 221. "That the Church carries forth the presence of Christ who brings forth the presence of God makes it a mystery and a sacrament," as Doyle puts it. "That this visible and flawed Church is at the same time the spotless Bride of the spotless Lamb makes it a paradox. In de Lubac's view, this Church is Christ present to us."

14. See de Lubac, Paradox and Mystery, 7ff, 52.

15. A contemporary, Nicolas Afanassieff, effectively performed the same service in the East, which was then developed further by John Zizioulas. The key text in which de Lubac develops this argument is Corpus Mysticum: Essai sur L'Eucharistie et l'Église au moyen âge (written in 1938/39, published in 1944).

16. See Henri de Lubac, At the Service of the Church: Henri de Lubac Reflects on the Circumstances that Occasioned His Writings, trans. Anne Elizabeth Eglund (San Francisco: Communio Books, 1993), 36. See also the discussions in Joseph Komonchak, "Theology and Culture at Mid-Century: The Example of Henri de Lubac," Theological Studies 51 (1990): 579602, and "Returning from Exile: Catholic Theology in the 1930s," in The Twentieth Century: A Theological Overview, ed. Gregory Baum (New York: Orbis, 1991), 35-48.

17. This is most prominent in his Catholicisme: les aspects sociaux du dogme, but is expressed across many of his other works as well. 
to all of humanity, so nothing can remain alien to the Church. ${ }^{18}$ He sought to expound how Christianity is concerned with the temporal order and "unites a transcendent destiny with social salvation." 19 Though the Church is supra-worldly, it is called to be the herald of unity and make the whole world one in Christ. ${ }^{20}$ For de Lubac, the unity which humankind seeks is found only in the catholicity of the Church which transcends all divisions, connects humanity with the transcendent, and honors both individual and collective. ${ }^{21}$

The broader social implications of this sacramental ecclesiology can be seen most prominently in his resistance to racist nationalism and anti-Semitism early in his career, during the Second World War and the Nazi occupation of France. He perceived these first and foremost as ecclesiological problems, since the catholic nature of the Church should undercut "racist nationalism" and "Hitlerian racism." ${ }^{22} \mathrm{He}$ characterizes his calling in the context of this crisis as performing "spiritual resistance" - attempting to awaken Christian consciences to the anti-Christian nature of the forces involved, to inspire social and political resistance. ${ }^{23}$ Through his public writings and clandestine activities, he pursued this agenda of reminding the Church of its mission in order to help it recover its task of being an inclusive social body in the world. ${ }^{24} \mathrm{He}$ denounced idolatrous forms of nationalism for the ways they redirect devotion from God and the Church to the nation, and he consistently emphasized Christian universalism in opposition to racism. The Church must reach out to all humanity, he insisted, to gather them into one and the same love. He charged the French bishops ${ }^{25}$ with a failure to protect the Church against the sin of racism and to guide it in its mission to care for the persecuted - thus resulting in a double miscarriage of the Church's social vision.

In short, de Lubac conceives of the Church as the "social embodiment of grace." ${ }^{26}$ It is an efficacious sign of salvation - of the reality which awaits completion in the eschaton. In the interim, the sacraments, and thus the Church, are signs of unity which make real a union with Christ and with others. As means of salvation, the sacraments naturally have a social dimension. They realize the unity among Christians for which all humankind was made, and thereby manifest God's saving intention for the world.

\section{Ecclesial Restriction of Sacramental Social Impact?}

It is at this point in tracing de Lubac's logic that Flipper raises his critical concerns. De Lubac asserts a sacramental relationship between the temporal and the eternal, between the historical and the eschatological in the Church - which is the social, embodied form of salvation that anticipates and mediates the kingdom. Why not, then, extend this to the Church's social and political practices in the broader public

18. See de Lubac, At the Service, 26; "The Authority of the Church in Temporal Matters," republished in Theological Fragments, trans. Rebecca Howell Balinski (San Francisco: Ignatius Press, 1989), 211.

19. This felicitous phrase is penned by Flipper. See "Henri de Lubac and Political Theology," 421.

20. See de Lubac's essay, "The Theological Foundation of the Missions," republished in Theology in History, trans. Anne Englund Nash (San Francisco: Ignatius Press, 1996).

21. See the essays republished in Nash's Theology in History under the section titled "Christian Resistance to Nazism and to Anti-Semitism."

22. These terms come up repeatedly in his essay, "Theological Foundation of Missions," mentioned above. See also his comments in At the Service, 43.

23. De Lubac discusses his involvement in the "spiritual resistance" at length in At the Service, 48-50.

24. See his comments in At the Service, 52, 426; and his "Letter to My Superiors," republished in Theology in History, as well as his essay, "L'Antisemitisme et la Conscience Chrétienne," Cahiers du Témoignage Chrétien, VI-VII (April-May 1942), reprinted in Résistance chrétienne au nazisme, ed. Renée Bédarida and Jacques Prévotat (Paris: Cerf, 2006).

25. These charges are leveled in Henri de Lubac, "Memorandum on French Bishops during the Occupation of France (19401944)," Journal of Jesuit Studies 5 (2018): 266-277.

26. This apt descriptor was coined in Susan Wood's seminal dissertation on de Lubac's ecclesiology: "The Church as the Social Embodiment of Grace in the Ecclesiology of Henri de Lubac" (PhD diss., Marquette University, 1986). 
sphere? Flipper's assessment of de Lubac's ambiguity on this point stresses the critical comments made in A Brief Catechesis on Nature and Grace regarding liberation theology:

"Liberation of man," understood as a social emancipation, is a human undertaking which, even when inspired by faith, brings about $[\ldots]$ by humans means certain changes in the organization of temporal society, and which becomes part of human history, with all the hazards [...] of going from bad to worse, which will always remain possible in this groping and sinful world. "Salvation in Jesus Christ," on the contrary, is essentially a divine undertaking which comes about in the depths of hearts and is inscribed in eternity. This makes clear the proper role of the Church; she is the messenger and bearer of this salvation and hence she cannot be assimilated, either in her structure or in her aims, to any of our human societies. ${ }^{27}$

A similar section in the same work displays a corresponding caution regarding notions of "progress":

We must, then, take care not to confuse the "progress of this world" (itself a very ambivalent term) with the "new creation." We must avoid slipping from conversion of the heart, by which the "new man" is born in Christ, to the unfolding of history (dialectic or not) that bears "as in its womb" the societies of the future. We shall not fail to distinguish as very different things the pursuit of a good social organization, or the determination of a more successful policy, and the beginning of the kingdom of God; they are two different orders of reality. ${ }^{28}$

According to Flipper's analysis, de Lubac's sharp distinction between liberation as a social program and liberation as freedom from sin results in a dualism that posits the "absolute transcendence of the grace of salvation with respect to the structures of political society" and cannot conceive of social progress in history as an anticipation of the promised kingdom. ${ }^{29}$ Flipper deems this a failure to apply the notion of sacramentality to the social and political practices of the Church for justice and liberation. ${ }^{30}$ De Lubac, according to Flipper, neglects to consider such efforts "within the sacramental economy of salvation as anticipatory of the eschatological kingdom."31 Flipper points here to the liberation theology of Gustavo Gutiérrez as a more fruitful approach to the question.

\section{Gutiérrez's Sacramental Ecclesiology}

In light of de Lubac's social and sacramental conceptions of salvation, it can seem ironic that he became a critic of liberation theology. ${ }^{32}$ The irony would appear compounded by the fact the one of its founding fathers, Gutiérrez, "cites de Lubac's retrieval of the social and historical aspects of Christian salvation as a source for the development of liberation theology" in his work, and adopts "the notion of the sacraments as essentially social, unitive, and transformative." ${ }^{33}$ He endorses de Lubac's rejection of "pure

27. Henri de Lubac, Brief Catechesis on Nature and Grace, 159f. This is the passage explicitly flagged by Flipper.

28. De Lubac, Brief Catechesis on Nature and Grace, 100-103.

29. Flipper, "Sacrament and Eschatological Fulfillment," 233.

30. See Flipper, "Sacrament and Eschatological Fulfillment," 237. See also Flipper, Between Apocalypse and Eschaton, 246-253; "Henri de Lubac and Political Theology," 437ff.

31. Flipper, Between Apocalypse and Eschaton, 237. Emphasis Flipper's.

32. See Hillebert, Henri de Lubac and the Drama of Human Existence, 210. Hillebert flags this issue and argues that it might be precisely because of the proximity of liberation theology to de Lubac's own project that he expressed such serious reservations about liberationist accounts of salvation. Hillebert pinpoints the primary issue on the uncritical appropriation of Marx in liberationist accounts of history. This essay discusses de Lubac's concerns with Marxism below, but also highlights de Lubac's critiques of the implicit "Joachimism" he saw in liberation theology and postconciliar accounts of progress.

33. These quotes come from the insightful essay by Gemma Simmonds: "The Mystical Body: Ecclesiology and Sacramental Theology," in T\&T Clark Companion to Henri de Lubac, ed. Jordan Hillebert (New York: Bloomsbury T\&T Clark, 2017), 171f. 
nature" in favor of the retrieval of the unity of the natural and supernatural orders, as well as the single human vocation to communion with God. ${ }^{34}$ The corresponding mission of the Church is from this point of view to embody the connection between nature and grace, which Gutiérrez describes in sacramental terms. The Church is called to be a sign of the reign of God and God's activity in the world. In fact, Gutiérrez himself identifies the concept of "sacrament" as "the central and most adequate category within which to understand the reality of the Church." 35 He wholeheartedly endorses Vatican II's new emphasis on the Church as a sacrament (largely inspired by the work of de Lubac), ${ }^{36}$ seeing it as "one of the most important and permanent contributions of the Council." ${ }^{37}$ Gutiérrez explains sacraments as efficacious signs which reveal God and his salvific plan in time - imparting union with God and the unity of humankind. ${ }^{38}$ From this perspective, the Church is the universal sacrament of salvation which leads history towards its fullness in Christ.

\section{Reasons for de Lubac's Reservations}

As Flipper notes, de Lubac "located the eternal ecclesially" 39 and was reticent to identify any political program or development with salvation or the eschatological kingdom. This tendency emerges most explicitly in de Lubac's postconciliar works, ${ }^{40}$ and it is therefore helpful to situate it within the context of the debates of the Council and its socio-political setting.

De Lubac recognized among modern Christians an increasing emphasis on earthly progress, ${ }^{41}$ which was often attended by a growing dismissal of $\mathrm{God}^{42}$ and the diminishment of the transcendent character of the Church. ${ }^{43}$ For this reason, de Lubac began to perceive the primary threat to the Church not as the extrinsicism he had battled earlier, but as a form of secular immanentism; not a "separated theology,"

34. See Gustavo Gutiérrez, A Theology of Liberation: History, Politics, and Salvation, rev. ed.; trans. Sister Caridad Inda and John Eagleson (Maryknoll, NY: Orbis, 1988), 44. See also Hillebert, Henri de Lubac and the Drama of Human Existence, 207. Hillebert remarks on Gutiérrez's appeal to de Lubac, but argues that Gutiérrez equivocates between the invitation to communion with God and the universal reception of grace already. This, according to Hillebert's analysis, indicates an intrinsicist inflection in de Lubac's original thesis.

35. James B. Nickoloff, The Church and Human Liberation: The Ecclesiology of Gustavo Gutiérrez (Phd diss., Graduate Theological Union, 1988), 284. See also Gutiérrez, Theology of Liberation, xliv. The present author is primarily a scholar of de Lubac and, though having read Gutiérrez's key text, Theology of Liberation, is less familiar with Gutiérrez's overall corpus. This essay relies heavily on the scholarship of Nickoloff regarding Gutiérrez's thought beyond that classic text.

36. See Joseph Cardinal Ratzinger, Principles of Catholic Theology, trans. Sister Mary Frances McCarthy, S. N. D. (San Francisco: Ignatius Press, 1982), 50. According to Ratzinger, "in all its comments about the Church [Vatican II] was moving precisely in the direction of de Lubac's thought." The Council described the Church as a sacrament in three of its four constitutions: on the liturgy, Sacrosanctum Concilium (SC 26); on the Church, Lumen Gentium (LG 1, 9, 48); and on the Church in the modern world, Gaudium et Spes (GS 42, 45).

37. Gutiérrez, Theology of Liberation, 145f.

38. See Gutiérrez, Theology of Liberation, $146 \mathrm{f}$.

39. Flipper, "Henri de Lubac and Political Theology," 438. See also Between Apocalypse and Eschaton, $252 \mathrm{ff.}$

40. See note 3 above. See also Cyril O'Regan, "A Theology of History," in T\&T Clark Companion to Henri de Lubac, ed. Jordan Hillebert (New York: Bloomsbury T\&T Clark, 2017), 300f. O'Regan argues that it would not be much of an exaggeration to say that addressing the modern temptation to confuse the kingdom of God with the kingdom of humanity "marks all of [de Lubac's] post-Vatican II work."

41. See de Lubac, Brief Catechesis on Nature and Grace, 262. De Lubac was already worried about progressivism during the Council. See Vatican Council Notebooks, vol. II, trans. Anne Englund Nash (San Francisco: Ignatius, 2016), 354f.

42. This is a theme that permeates many of de Lubac's writings. De Lubac sees in much of modern thought, including that of many Christians, a concern for exclusively temporal realities to the neglect of transcendent ones. Modern persons are inclined in his eyes to an absolute temporalism and technological intoxication, thinking that, through the achievements of science, humanity can save itself and cure the world of all ills. Christians themselves feel this secularist temptation, he believes, obscuring their radical dependence upon God and the primacy of the heavenly kingdom as they join their neighbors in constructing the earthly kingdom.

43. See de Lubac, At the Service, 346, 362. See also Walsh, "De Lubac's Critique of the Postconciliar Church," 406f. Walsh highlights the fact that de Lubac's main concern was the loss of the sense of the transcendent in the Church. This, according 
but a "separated philosophy." 44 Through a false idea of "openness to the world," 45 a secularist temptation ${ }^{46}$ had arisen, he argued, which sought to achieve progress through utilitarian and technological means. ${ }^{47}$ In de Lubac's estimation, this was a mirror image of the previous separation of nature and the supernatural that had led to an imposition of the supernatural on the social, which he referred to as "integrism." For de Lubac, the threat at this point was a form of integrism from the opposite direction ${ }^{48}$ - the reduction of theology to a quasi-sociology. Such a move would abandon the sacramental ontology which he had fought so diligently to reestablish. ${ }^{49}$ Modern progressive movements and their representative intellectuals embody a new form of positivism, he asserted - they fail to distinguish what is "beyond science" from what is "against science," and in their reductive empiricism they discard transcendence and mystery. ${ }^{50}$ De Lubac worried that this "inverse integrism" ${ }^{51}$ had crept into much postconciliar theology. ${ }^{52}$ Discussions of the Church's mission in the world appeared to absorb the old dualism of "pure nature" - now expressed in a humanist mode. Increasingly, figures began calling for Christians to collaborate with all persons to reconstruct the world without reference to humanity's supernatural vocation. De Lubac became increasingly concerned that the neo-scholastic dualism that he had battled in the first part of his career was being replaced by a secular progressivism. ${ }^{53}$

De Lubac addressed these concerns by reiterating his long-held belief that Christianity is a humanism, ${ }^{54}$ but expressed this with the following caveat: "secular humanism is the absolute antithesis of

to Walsh's interpretation of de Lubac, was the fundamental cause of the postconciliar crisis: the modern tendency to "naturalize" the mystery of the Church - i.e., "secularism."

44. This is Hans Boersma's way of framing it. See Hans Boersma, Nouvelle Théologie \& Sacramental Ontology: A Return to Mystery (Oxford: Oxford University Press, 2009), 262. De Lubac himself used these terms throughout his career, as early as his inaugural lecture in October of 1929 as a newly installed faculty member at the University of Lyons. See "Apologetics and theology," republished in Theological Fragments, trans. Rebecca Howell Balinski (San Fransisco: Ignatius, 1989).

45. See de Lubac, At the Service, 150.

46. See de Lubac, Brief Catechesis on Nature and Grace, 41, 110; "Teilhard and the Problems of Today," in The Eternal Feminine: A Study on the Text of Teilhard de Chardin, trans. René Hague (New York: Harper and Row, 1972), 180f; Mystery of the Supernatural, trans. Rosemary Sheed (New York: Herder and Herder, 1967), xi-xii.

47. See de Lubac, Paradox and Mystery, 48ff.; Henri de Lubac, Motherhood of the Church, 141ff.

48. De Lubac makes these comparisons in At the Service, 149, 367; Vatican Council Notebooks, 2: 380.

49. This is closely related to Hillebert's account of the paradoxical dynamic between nature and grace. The present author prefers to foreground the image of sacrament to understand de Lubac's larger project. This relates to the comment mentioned above about de Lubac's attempt to properly reunite nature and grace, salvation and sociality, etc. The image of sacrament for the Church functions to foreground three essential aspects of salvation: salvation, according to de Lubac, is social, supernatural (i.e., distinct from, integrally related to, but beyond the grasp of nature; transcendent, eschatological), and mediated. This mediated aspect is not as readily apparent within the paradoxical account, but this aspect is central in de Lubac's critiques of the Joachimism he perceived in much of postconciliar theology.

50. De Lubac, Brief Catechesis on Nature and Grace, $29 \mathrm{ff}$.

51. This term was coined by Aaron Riches. See Aaron Riches, "Henri de Lubac and the Second Vatican Council," in T\&T Clark Companion to Henri de Lubac, ed. Jordan Hillebert (New York: Bloomsbury T\&T Clark, 2017), 135.

52. De Lubac's critical remarks on troubling trends in postconciliar theology are littered throughout At the Service, L'Église dans la crise actuelle (Paris: Cerf, 1969), Entretien autour de Vatican II: Souvenirs et reflexions (Paris: France CatholiqueCerf, 1985), and "Teilhard and the Problems of Today [Teilhard et notre temps]," in The Eternal Feminine: A Study on the Text of Teilhard de Chardin, trans. René Hague (New York: Harper and Row, 1972 [1968]). For more on this theme, see Walsh, "Henri de Lubac and the Ecclesiology of the Postconciliar Church;" "De Lubac's Critique of the Postconciliar Church."

53. These trends were exhibited and perpetuated by what de Lubac somewhat cryptically refers to as the "para-council." See the discussions in Walsh, "De Lubac's Critique of the Postconciliar Church," 416ff; and Hillebert, Henri de Lubac and the Drama of Human Existence, 206ff. See also de Lubac, L'Église dans la crise actuelle (Paris: Cerf, 1969), 43-52; “The Council and the Para-Council," appendix C in Brief Catechesis on Nature and Grace.

54. This is a divergence from the general thrust of Hillebert's recent book. Hillebert is much more reticent to see in de Lubac a promotion of humanism. He perceives de Lubac as performing a more subversive and critical attack against the various "humanisms" which were in vogue after World War II. The present author agrees with Patrick X. Gardner that, though de Lubac was critical of secular humanisms and cautions against uncritical adoption of humanistic views on offer, he promotes 
the Gospel." 55 The two main sources inspiring the forms of modern humanism which trouble de Lubac in this postconciliar context are Karl Marx (1818-1883) and Joachim of Fiore (1135-1202). He had confronted Marxist thought already in 1938 in portions of Catholicism, ${ }^{56}$ and continued to engage these ideas throughout the rest of his life. ${ }^{57}$ His most direct attack on Marxism is found in the 1947 essay, "The Search for a New Man." 58 This essay launches from the Marxist appeals to un homme nouveau, which was conceived as the human person in full self-possession. De Lubac's main concern with Marxism is its radical denial of transcendence. From de Lubac's point of view, it is a merely temporal program permeated by spiritual negations. ${ }^{59}$ It denies the deep wound of sin and the need for the supernatural. Its solutions are materialistic and technocratic. ${ }^{60}$ De Lubac rejected all such thinking, and his positions are emphatically reiterated when he responds to accusations of flirtations with communism and reproduces a letter to a young friend inquiring about his views on "progressive Christians." 61

Communism and other progressive social visions inspired by Marxist ideas were, in short, explicitly opposed by de Lubac. He also came to perceive a connection between Marxism and the thought of Joachim, ${ }^{62}$ and he would argue that the latter undergirded the major errors in ecclesiology and political theology in modern times. ${ }^{63}$ De Lubac accordingly described the modern transmutation of the search for the kingdom of God into the pursuit of social utopias as "Joachimism." 64 Secular humanists inspired by Hegel and Marx were heirs of the eschatology of Joachim, who posited the final age of history as one characterized by a "spiritual" Church beyond the mediation of signs and sacraments. According to de Lubac's interpretation, Joachimism immanentizes the eschaton and de-institutionalizes salvation in the age of the Spirit; thus, it effectively denies notions of mediation and sacramentality. In contrast, de Lubac's eschatology conceives of the time between Christ's comings as characterized by a tension between total consummation in the future and proleptic anticipation in the present - making the sacraments both possible and indispensable. ${ }^{65}$ For this reason, de Lubac was convinced that the Church as the sacrament of Christ will never be surpassed in its visible form, nor could its mystery be reducible to sociology.

a "converted humanism." See Patrick X. Gardner, "An Inhuman Humanism" in T\&T Clark Companion to Henri de Lubac, ed. Jordan Hillebert (New York: Bloomsbury T\&T Clark, 2017).

55. This quote is from another of de Lubac's postconciliar texts: Pic de la Mirandole: études et discussions (Paris: AubierMontaigne, 1974); quoted in Milbank, Suspended Middle, 10. See de Lubac's earlier statements in the essay, "A Christian Explanation of our Times" ["Explication Chrétienne de notre temps"] republished in Theology in History [1941]. There de Lubac discusses danger of extracting humanistic ideals from their Christians origins. On page 442, de Lubac argues that, in laicizing these Christianly-inspired ideals, they become "ineffective and indeed dangerous. Ideals fallen to the ranks of ideologies and utopias." See also Henri de Lubac, The Drama of Atheist Humanism [Le drame de l'humanisme athée], trans. Edith M. Riley, Anne Englund Nash, and Mark Sebanc (San Francisco: Ignatius Press, 1995 [1944]), 19, 426f.). There, de Lubac had expressed that Christian humanism rests on the Christian paradox of a freedom which is open to transcendence. When transcendence is lost and humanity is venerated, dehumanization results.

56. See de Lubac, Catholicism, $357 \mathrm{ff}$.

57. See Hillebert, Henri de Lubac and the Drama of Humanity Existence, 135.

58. Henri de Lubac, "L'idée chrétienne de l'homme et la recherche d'un homme nouveau," Études 255 (1947). This was republished in part 4 of Drama of Atheist Humanism.

59. See de Lubac, Drama of Atheist Humanism, 432, 438.

60. See de Lubac, Drama of Atheist Humanism, 457ff.

61. See the letter reproduced in de Lubac, At the Service, 239ff.

62. See chapter 17 of La Postérité spirituelle de Joachim de Flore (Paris: Cerf, 2014).

63. De Lubac had already discussed the thought and influence of Joachim in scattered places in his pre-conciliar works, such as Méditation sur l'Église and Exégèse Médiévale: Les quatre sens de l'Écriture, 4 vols. (Paris: Aubier, 1959-1964). This theme becomes a major focus of his writings in the postconciliar period.

64. See de Lubac, At the Service, 156f. De Lubac discusses this them in many places across his corpus, but this is the focus of his major postconciliar work which remains untranslated to this day: La Postérité spirituelle de Joachim de Flore. For more on this theme, see Patrick X. Gardner, "Modern Pentecost: Henri de Lubac on Atheism and the Spiritual Posterity of Joachim of Fiore" (PhD diss., Notre Dame, 2015).

65. In this respect, this essay strongly agrees with Hillebert. See his comments in Henri de Lubac and the Drama of Human Existence, 146-159. 
These details are important to keep in mind when reading de Lubac's A Brief Catechesis, which was written during the Cold War, when much Christian reflection on the kingdom of God and historical progress became increasingly inflected by Marxist thought. This was particularly true, in de Lubac's estimation, of the nascent liberation theology. In the aftermath of Vatican II, de Lubac perceived Joachimist thinking among many progressive Catholics. De Lubac's sharpest statements about humanistic action came in his critique of Edward Schillebeeckx (1914-2009). ${ }^{66}$ Schillebeeckx had famously employed the phrase "sacrament of the world" to represent the teaching of the Council on the Church. De Lubac was willing to speak of the Church as sacrament for the world, or the sacrament of the coming kingdom of God, but worried that Schillebeeckx's construal would elide the distinction between nature and the supernatural, ${ }^{67}$ and render the Church a sacrament of grace already immanent in creation. For de Lubac, this vision failed to account for the newness wrought in creation through Christ, and the transcendent nature of the Church as an efficacious sign of grace. The Church would offer nothing unique to the world, and simply join it in the technical construction of a new socio-political order. History itself would become the sacrament, and the eschatological kingdom would be merely the endpoint of secular progress. The Church would from this point of view be a naturalized collaborator in achieving the kingdom, rather than a mystical sacrament of the supernatural transfiguration of the world.

In light of this, de Lubac's comments about liberation and progress are understandable, and they also exhibit significantly more nuance than Flipper acknowledges. ${ }^{68}$ De Lubac cannot properly be interpreted as simply denouncing liberation theology, since he argues that liberation theologians are not utopians, and that Christians "should be the first to consecrate their efforts" 69 to serving humanity and society in the here and now. And although de Lubac expresses reservations about "progress," his comments are followed immediately by words of moderation. ${ }^{70}$ Certainly, de Lubac argues, one must not fail to distinguish "the pursuit of a good social organization [...] and the beginning of the kingdom of God." On the other hand, "no matter how fundamental and how strict such a distinction may be, it must not be understood as a separation. The two pursuits are in a reciprocal relation: "[I]t can be legitimate, without pursuing utopias, to seek in such a society some sort of 'parable,' some distant foreshadowing of the Kingdom."

While sympathetic to some of the goals of liberation theology, then, de Lubac remained concerned that it could reduce theology to sociology, and the role of the Church to a mere human organization. ${ }^{71}$ If the Church abandons its primary task of reminding mankind of its supernatural vocation by merely echoing the socio-political wisdom of the world, he insisted, it will thereby lose its soul and become a secular parasite. Such a Church should simply disappear. Liberation theology, according to de Lubac, can also confuse the divine initiative in salvation with the human undertaking of alterations to temporal society, ${ }^{72}$ and lose sight

of the personal nature of sin and the need for conversion. ${ }^{73}$ As the next section shows, de Lubac could therefore not always see eye to eye with a proponent of liberation theology like Gutiérrez.

66. This discussion is found in appendix B of Brief Catechesis on Nature and Grace, titled "The 'Sacrament of the World?", 67. As Hillebert effectively explains in his recent book, de Lubac consistently argued for the heterogeneity between nature and grace/the supernatural. This point is a key thesis in Hillebert's book, Henri de Lubac and the Drama of Human Existence. 68. In Flipper's dissertation, he even characterizes de Lubac's view of liberation theology as simply rearranging deck chairs on the sinking ship of history. See Flipper, "Sacrament and Eschatological Fulfillment," 235. This is a gross caricature of de Lubac's thought. Thankfully, Flipper has excluded such comments in subsequent publications.

69. De Lubac, Brief Catechesis on Nature and Grace, 106.

70. The following quotes a from de Lubac, Brief Catechesis on Nature and Grace, 100-103.

71. See de Lubac, Brief Catechesis on Nature and Grace, 109-113.

72. See de Lubac, Brief Catechesis on Nature and Grace, $158 \mathrm{f}$.

73. See de Lubac, Brief Catechesis on Nature and Grace, $136 \mathrm{f}$. 


\section{Divergence between the Systems of de Lubac and Gutiérrez}

The differences between the approaches of de Lubac and Gutiérrez are numerous, including the contrasting emphases they highlight in Vatican II's constitution on the Church in the modern world, Gaudium et Spes, particularly with reference to this quote: "[E]arthly progress must be carefully distinguished from the growth of Christ's kingdom. Nevertheless, to the extent that the former can contribute to the better ordering of human society, it is of vital concern to the kingdom of God" (GS 39). Gutiérrez privileges the close relationship between temporal progress and the growth of the kingdom which he sees expounded here by the constitution, ${ }^{74}$ whereas de Lubac prefers to foreground the distinction thus upheld. De Lubac wants to make clear that one cannot identify progress with salvation, ${ }^{75}$ and Gutiérrez argues that one cannot separate them. Gutiérrez envisions a substantial convergence between the Church's evangelizing mission and "the utopian project of emancipation and creation of a new human being and a qualitatively different society." ${ }^{, 76}$ Since salvation pertains to the whole person and this world, the building up of temporal society is an integral part of the saving process. ${ }^{77}$ Temporal progress - or human liberation - is an essential component of the growth of the kingdom in history, according to Gutiérrez. ${ }^{78}$ Eschatological hope works to transform the present conditions of society. ${ }^{79}$

This identification of social progress with the kingdom of God is more than de Lubac could countenance. ${ }^{80}$ De Lubac insists in his writings upon the miraculous nature of salvation as a divine gift, which means that the kingdom cannot be won by political struggles or conquered through social efforts. ${ }^{81}$ This does not deny the imperative to promote true human "liberation" as far as one can, but one must also protect oneself from quixotic hopes. One must also beware of the fact that all human achievements are ambivalent, and the possibility that the best social organization might, in fact, lead people away from the kingdom. ${ }^{82}$ There is a link between social liberation and salvation, but to harmonize them faithfully the Church must prioritize the proclamation of liberation from $\sin .{ }^{83}$ Whereas Gutiérrez perceives a fruitful ambiguity in the conciliar constitution on the Church in the Modern World, de Lubac discerns a careful balance and clear distinctions between earthly progress and the growth of Christ's reign. ${ }^{84}$

One particularly striking contrast between the two approaches involves Gutiérrez's notion of the "de-centering" or "uncentering" of the Church - an essential component of his understanding of sacramental ecclesiology. ${ }^{85}$ As a sacrament of salvation - or human liberation in history - the Church must carry out its mission in a way free of "ecclesiocentrism." Mission ad extra constitutes the raison d'être of the Church, which must be carried out in fidelity to struggle for the poor. ${ }^{87}$ The Church actualizes itself through transc-

74. See Gutiérrez, Theology of Liberation, 99.

75. See de Lubac, Brief Catechesis on Nature and Grace, 229.

76. Nickoloff, Ecclesiology of Gutiérrez, 309. See also Gutiérrez, Theology of Liberation, 38. Gutiérrez argues that Lumen Gentium and Gaudium et Spes do not clearly distinguish the two missions of evangelization and the inspiration of the temporal sphere through lay persons.

77. See Gutiérrez, Theology of Liberation, 85-97.

78. See Gutiérrez, Theology of Liberation, 104.

79. See Gutiérrez, Theology of Liberation, 121-135.

80. And alongside this, Gutiérrez also explicitly endorses Schillebeeckx's views. See Gutiérrez, Theology of Liberation, 8ff. 81. See de Lubac, Brief Catechesis on Nature and Grace, 106ff.

82. See de Lubac, Brief Catechesis on Nature and Graces, 104. Hillebert brings up these same points in his conclusion. See Henri de Lubac and the Drama of Human Experience, $210 \mathrm{f}$.

83. See de Lubac, Brief Catechesis on Nature and Grace, $160 \mathrm{ff}$.

84. See de Lubac, Brief Catechesis on Nature and Grace, 229.

85. See Nickoloff, Ecclesiology of Gutiérrez, 284. See also Gutiérrez, Theology of Liberation, 143ff. Mention of "uncentering" occurs at the opening of his chapter on Church as "sacrament." Gutiérrez proceeds to link the sacramentality of the Church with a divergence from the former predominance of an "ecclesiocentric emphasis."

86. See Nickoloff, Ecclesiology of Gutiérrez, ii-iii.

87. See Nickoloff, Ecclesiology of Gutiérrez, xlii, 285. 
ending its own boundaries and thus embodying the universal sacrament of salvation. ${ }^{88}$ Invoking Karl Rahner (1904-1984) and Schillebeeckx, Gutiérrez argues that the frontiers of the Church and world must become more fluid. The Church must acknowledge the universal action of divine grace in phenomena like "anonymous Christianity" 89 and "become world." "We can," Gutiérrez asserts, "no longer speak properly of a profane world." 91 The building of a just society is salvific work which can be performed by Christian and non-Christian alike. ${ }^{92}$ We must, according to Gutiérrez, avoid "reducing the salvific work to the action of the Church [...] for the Church must cease considering itself as the exclusive place of salvation and orient itself towards a new and radical service of people." 93 As the "sacrament of saving unity" (LG 9) and the "universal sacrament of salvation" (LG 48), the Church's existence is "for others," and its center is outside itself. $^{94}$

The other unique way in which Gutiérrez conceives of the Church's renunciation of ecclesiocentrism concerns its nature as a sign under the eschatological proviso. ${ }^{95}$ The Church is not "nonworld," 96 but the People of God in history, oriented toward the future promised by the Lord. To accept poverty and oppressive conditions is to deny the future and retrogress back into conditions of servitude analogous to those that preceded the liberation of God's people under Moses from the heavy hand of Pharaoh. ${ }^{97}$ As God's new covenant people, Christians must rather perceive that the work of Christ is a "new creation" which entails a liberation from sin and all its consequences - including injustice and the oppressive structures of poverty. The Exodus is paradigmatic, Gutiérrez argues, as emphatically shown in the institution of the Eucharist as a Christian Passover. ${ }^{98}$ The poor neighbor is a sacrament; ${ }^{99}$ and humankind, made in the image of God, is "the sacrament of God." 100 Therefore, "to oppress the poor is to offend God," whereas "to know God is to work for justice among human beings."

In contradistinction to all this, according to de Lubac's sacramental ecclesiology the Church is the sacrament neither of history (Gutiérrez) nor of the world (Schillebeeckx); it is first and foremost the sacrament of Christ. ${ }^{101}$ As such, it aims to carry the hope of the world, rather than join the world in pursuit of its hopes. ${ }^{102}$ The Church certainly burns with a passion for mission, and thus exists "for others;" 103 but this in no way leads to a loss of the Church at the center of God's work in the world. Rather, the Church is

88. See Nickoloff, Ecclesiology of Gutiérrez, 329f.

89. For a summary of Rahner's theory of an “anonymous Christian," see Richard Lennan, The Ecclesiology of Karl Rahner (Oxford: Oxford University Press, 1995), 38ff. Lennan explains that Rahner developed the theory in an attempt to harmonize the teaching that outside the Church there is no salvation with the fact that Christians were an ever-decreasing minority in increasingly secularized societies. Even before the Council, Rahner promoted an explicit offer of grace in the Church as well as an "anonymous" offer outside it. Rahner grounded this in his view that the Incarnation had forged the whole of humanity into the people of God. Thus, according to Lennan, Rahner "interpreted the certainty of God's offer within the Church as sacrament of what is actually offered to all." After Vatican II, Rahner expanded on this theory in order to reconcile the Council's teaching on the necessity of church for salvation (Lumen Gentium 14) with the declaration that all who act in good faith can attain salvation (Lumen Gentium 16); to harmonize God's universal salvific will (Ad Gentes 3; Gaudium et Spes 2) with the Council's affirmation of the salvific value of non-Christian religions (Nostra Aetate 2).

90. See Gutiérrez, Theology of Liberation, 45.

91. Gutiérrez, Theology of Liberation, 84.

92. See Gutiérrez, Theology of Liberation, 46.

93. Gutiérrez, Theology of Liberation, 143f.

94. See Gutiérrez, Theology of Liberation, 147.

95. See Gutiérrez, Theology of Liberation, 128.

96. Gutiérrez, Theology of Liberation, 147.

97. See Gutiérrez, Theology of Liberation, 168.

98. See Gutiérrez, Theology of Liberation, 90.

99. See Gutiérrez, Theology of Liberation, 115.

100. Gutiérrez, Theology of Liberation, 168. Emphasis Gutiérrez's. The following quotations are from the same page.

101. See Wood, "Social Embodiment of Grace," 201. See also the entirety of chapter 6, titled "The Sacrament of Christ," in de Lubac, Splendor.

102. See de Lubac, Paradox and Mystery, 9.

103. See de Lubac, "Theological Foundation of Missions," 388-394. 
seen as both a means of salvation and an end of creation. While the kingdom and the Church cannot be completely identified, neither can they be dissociated. The predominant task of its mission is, then, to bring persons into this fellowship and to "construct this City." 104 The Church must serve the world, but for the saving of the world - directing it to its destiny. As sign and sacrament, the Church is intended to lead the world to the reality it signifies. It can thus be said that in some sense, "[the world] was made for the Church, to be assumed into, saved, and transfigured by her." 105 So while de Lubac can wholeheartedly espouse Christian humanism, it must be a "converted humanism," 106 rather than a baptized secular humanism. ${ }^{107}$ The alternative to extrinsicism is not immanentism, but transformation, incorporation, and new creation. ${ }^{108}$ The kingdom cannot be established by political processes alone, ${ }^{109}$ and humankind must not be considered as its own end. The "new human" must be birthed in the Church, ${ }^{110}$ and humanity must undergo conversion. This means that Exodus is achieved only through the Cross - a motif which de Lubac foregrounds significantly more than Gutiérrez. ${ }^{111}$ While de Lubac argues that Christianity is a "revolt against destiny," 112 and thus inspires "genuine commitment to human progress which entails the undoing of social injustice," 113 he maintains that the deep wound in humanity will never be totally healed by earthly means, and that progress will not lead along a direct line into the eschatological Kingdom.

\section{Convergence between the Systems of de Lubac and Gutiérrez}

The significant differences just outlined should not obscure the level of substantial agreement between de Lubac and Gutiérrez in terms of the social implications of their respective sacramental ecclesiologies. As mentioned above, both reject the "pure nature" scheme ${ }^{114}$ for an integral vision. ${ }^{115}$ For both, salvation and sin cannot be reduced to private and individual concerns; rather, they are historical and social facts which bear upon temporal life. ${ }^{16}$ Theology must, then, be "de-privatized"117 and the Church's sphere of concern must be understood as the totality of creation. ${ }^{118}$ Equally evident is the fact that for neither

104. De Lubac, "Theological Foundation of Missions," 390ff. De Lubac argues that the Church is "already, here below, in mystery, the figure of that final and transcendent reality; the Church, who gathers human being into the unity of her body; the Church, the true Jerusalem, within whom all creation of man must find its place in order to be transfigured there." Though not perfectly identified, the Church and the heavenly city cannot be neatly distinguished. The Church is the symbolic anticipation, the sacrament of the heavenly city. Thus, it is both a means and an end of Christian mission - an instrument and site of salvation.

105. De Lubac, Paradox and Mystery, 53f.

106. De Lubac, Catholicism, $367 \mathrm{ff}$.

107. See de Lubac, Brief Catechesis on Nature and Grace, $92 \mathrm{ff}$.

108. See Wood, "Social Embodiment of Grace," 191ff; "The Nature-Grace Problematic within Henri de Lubac's Christological Paradox," Communio 19 (Fall 1992), 398; "Henri de Lubac and the Church-World Relationship in Gaudium et Spes," in The Legacy of Vatican II, ed. Massimo Faggioli and Andrea Vicini (New York: Paulist, 2015), 243.

109. See de Lubac, "Authority of the Church in Temporal Matters," 232. "[T]he Church is seeking in the most diverse ways to elevate her children above the all-too-human views that conceive of the kingdom of God in the same way that they conceive of establishments of the world. And this misconception causes them to seek its advent by political processes rather than an incessant interior reform and spiritual discipleship."

110. See de Lubac, Motherhood of the Church, 120.

111. See de Lubac, Catholicism, 368. See also Wood, "Social Embodiment of Grace," 193.

112. De Lubac, Drama of Atheist Humanism, 419f.

113. Francesca A. Murphy, "De Lubac, Grace, Politics and Paradox," Studies in Christian Ethics 23, no. 4 (2010): 426.

114. See Gutiérrez, Theology of Liberation, 41ff. Starting on page 44, Gutiérrez acknowledges the influence of de Lubac in this regard.

115. See Gutiérrez, Theology of Liberation, 45. Gutiérrez claims that "integral" is the "key word" of Gaudium et Spes.

116. See Gutiérrez, Theology of Liberation, xl, 85, 97, 102.

117. See Gutiérrez, Theology of Liberation, $126 \mathrm{ff}$.

118. See Flipper, "Henri de Lubac and Political Theology," 440; Nickoloff, Ecclesiology of Gutiérrez, 289. See also Gutiérrez, Theology of Liberation, 101, where Gutiérrez denounces the separation of orders. Even Milbank, the harsh critic 
theologian does this entail a theocratic vision. ${ }^{119}$ The Church's primary task in the public sphere, as it pertains to temporal matters, is to address the human conscience (de Lubac); ${ }^{120}$ or, in other words, to perform “conscientization" (Gutiérrez). ${ }^{121}$

Moreover, for all of Gutiérrez's concern for political and social re-ordering, he does not ignore the necessity of faith. ${ }^{122}$ To him, sacrament and evangelization are complementary concepts, and evangelization is always an ecclesial task. ${ }^{123}$ A close reading of Gutiérrez indicates that he does not characterize the Church's mission as primarily political or economic; rather, he conceives its kingdom message as having "unavoidable consequences in social, political, and economic life." ${ }^{124}$ Partnership with the world should therefore in no way dilute the uniqueness of the Christian community or its message. ${ }^{125}$ Gutiérrez is also clear that the Church's engagement with Marx's thought must involve "direct and fruitful confrontation." 126 The Church must boldly proclaim the truth it has humbly received from Christ rather than merely parrot the best insights of secular sociology, philosophy, or political theory.

The most significant area of convergence between the systems of de Lubac and Gutiérrez pertains to sacramental mission and practice. As the sacrament of Christ and his Kingdom, it is the task of the community to make visible the implications of Christ's saving work in history. ${ }^{127}$ It is imperative, therefore, that the Church seek to bear a better resemblance to the Kingdom. The internal structure of the Church should signify the salvation it announces. For de Lubac this meant the rejection of all forms of racism in the Church, by virtue of its catholic mission and the common destiny of humankind. For Gutiérrez this meant becoming a "Church of the poor," in line with the liberating contours of salvation and the privileged place of the poor in the kingdom of God. ${ }^{128}$ For him, to be an efficacious sign of unity, liberation, salvation, and the reign of God, the Church must be reconciled with the poor and lift up the lowly. Otherwise, the sacramental mystery remains imperceptible in the world. Mission ad extra, therefore, must shape the realities of the Church ad intra, not merely flow from them.

This last point has profound implications for the Eucharist. Like de Lubac, Gutiérrez argues that the Eucharist is at the center of the Church, and constitutes its core task. ${ }^{129}$ It creates the community and is meant to be shared. ${ }^{130}$ Therefore, according to de Lubac, the unity signified by the Eucharist should culminate in the sending out of the Church with its mission to bring divine charity to the wider world. ${ }^{131}$ Gutiérrez argues further that the Eucharist also demands reconciliation and justice - which entails a real

of liberation theology, admits this about the movement. See John Milbank, Theology and Social Theory: Beyond Secular Reason (Oxford: Blackwell, 1990), 228.

119. See Flipper, "Henri de Lubac and Political Theology," 438f.; de Lubac, "Authority of the Church in Temporal Matters," 213f., 220; Brief Catechesis, 110; Gutiérrez, Theology of Liberation, 34ff., 145, 153.

120. See notes 22 and 23 above.

121. See Gutiérrez, Theology of Liberation, xxiv, 57, 69ff. Gutiérrez builds on Paulo Freire's "pedagogy of the oppressed" to develop his theory of conscientization. This is primarily oriented to raising the consciousness of the persons in oppressive circumstances to enable them to rightly perceive their situation and regain a sense of agency to address it, becoming agents in the transformation of society. Gutiérrez expands on this and attaches it to the prophetic role of the Church to denounce these injustices and raise up the oppressed. He thereby closely associates evangelism and conscientization.

122. See Nickoloff, Ecclesiology of Gutiérrez, 292.

123. See Gutiérrez, Theology of Liberation, xli; Nickoloff, Ecclesiology of Gutiérrez, 285.

124. Nickoloff, Ecclesiology of Gutiérrez, 296.

125. See Nickoloff, Ecclesiology of Gutiérrez, $302 \mathrm{f}$.

126. Gutiérrez, Theology of Liberation, 8.

127. See Gutiérrez, Theology of Liberation, 147; Nickoloff, Ecclesiology of Gutiérrez, 301f.

128. See Gutiérrez, Theology of Liberation, xlii, 147, 160f; Nickoloff, Ecclesiology of Gutiérrez, 312ff.; $331 \mathrm{ff}$.

129. See Gutiérrez, Theology of Liberation, 148; Nickoloff, Ecclesiology of Gutiérrez, 333.

130. See Gutiérrez, Theology of Liberation, 149; de Lubac, Splendor, 133. See also Paul McPartlan, The Eucharist Makes the Church: Henri de Lubac and John Zizioulas in Dialogue (Fairfax, VA: Eastern Christian Publications, 2006).

131. See de Lubac, Catholicism, 35-50. 
commitment to act against oppression and alienation. ${ }^{132}$ Otherwise, the sacrament is empty and disharmonious with the reality to which it refers.

\section{Returning to Flipper's Charges}

In light of the preceding analysis, we are better prepared to address the charges laid by Flipper. As demonstrated above, de Lubac is clearly concerned about Christianity making an impact beyond the liturgical fellowship of the sacramental community. This broader social vision operates according to his sacramental logic. Grace works like leaven, transforming nature from inside. The Church, then, "influences" and "ennobles" the state and surrounding society - inspiring them to become more Christian and thus "more human." 133 Within the broader political realm in which it resides, the Church must make a cultural contribution: "She must devote herself freely to her task as educator in order to help the country remake itself by helping it go beyond itself." 134 De Lubac can admit, even within the work expressing his strongest criticisms of "progress," that the Church has borne fruit in this regard. Though the world has never witnessed a perfect "Christian nation," he argues, the student of history must note many societal achievements due to the influence of Christianity. ${ }^{135}$ In the same work, de Lubac also affirms the idea of a "positive relationship" between temporal progress and the coming reign of God, and argues that it is legitimate to seek societal progress as a "parable" of the coming Kingdom. ${ }^{136}$ He clearly envisioned his own efforts of "spiritual resistance" to Nazism and anti-Semitism in this way.

De Lubac was not opposed to liberation theology's commitment to welcome those who have been wrongly marginalized, to assist those who have been oppressed, or to challenge the Christian community through conscientization. Much of this accords quite well, in fact, with de Lubac's sacramental vision, as such commitments would assist the Church in becoming a more credible sign of Christ and his saving work in the world. De Lubac's reservations about liberation theology pertain to the tendency - which he saw as broadly shared with various other forms of political theology that emerged after the Council - to equate earthly "progress" and the kingdom of God. He was also worried about its connections with Marxism, ${ }^{137}$ which might promote merely political action in addressing social problems. De Lubac would rather promote a form of "spiritual" resistance to destructive forces. One could imagine de Lubac writing a book, for example, with the title Christian Resistance to Oppressive Structures of Poverty. ${ }^{138}$ This would not be inconsistent with the fundamental principles of his sacramental ecclesiology, provided the Church is not

132. See Gutiérrez, Theology of Liberation, 150.

133. De Lubac, "Authority of the Church in Temporal Matters," 212.

134. De Lubac, "Christian Explanation of Our Times," 455.

135. See de Lubac, Brief Catechesis on Nature and Grace, 88f. "[F]or example the changes in Roman law which followed the conversion of Constantine, the patient education of a still barbarous Europe, the many institutions created during the Middle Ages to further the cause of peace and protect the weak against secular power, the widespread reaction against the brutality of morals."

136. See de Lubac, Brief Catechesis on Nature and Grace, $102 \mathrm{f}$.

137. At the time of de Lubac's writings, liberation theology was still in its early stage of development. This was prior to the official statement in 1984 by the Congregation for the Doctrine of the Faith (CDF), titled "Instruction on Certain Aspects of the "Theology of Liberation," critiquing the associated theologians 'dependence on conceptual tools borrowed heavily from Marxism. Once the connections with certain anti-Christian Marxist aspects had been addressed, reformed versions of liberation theology became more acceptable, and the Church could embrace its profitable contributions. For example, a couple years immediately following the publication of the DCF document that critiqued aspects of liberation theology, the same body produced another document on the subject ("Instruction on Christian Freedom and Liberation") which explicitly promulgated liberation theology's teaching on the "preferential option for the poor" - now a key principle of Catholic Social Teaching.

138. This is a wordplay on de Lubac's work, Christian Resistance to Anti-Semitism: Memories from 1940-1944 [Résistance chrétienne à l'antisémitisme: souvenirs 1940-1944], trans. Elizabeth Englund Nash (San Francisco: Ignatius Press, 1990 [1988]). 
The Social Good $\diamond 29$

lost as the central site and instrument of salvation - the sacrament which proleptically embodies and points to the eschatological fullness that cannot be achieved through humanity's resources alone. 


\section{Bibliography}

\section{Vatican Documents}

Lumen Gentium (Dogmatic Constitution on the Church), November 21, 1964.

Unitatis Redintegratio (Decree on Ecumenism), November 21, 1964.

Nostra Aetate (Declaration on the Relation of the Church to Non-Christian Religions), October 28, 1965.

Sacrosanctum Concilium (Constitution on the Sacred Liturgy), December 4, 1965.

Ad Gentes (Decree on the Missionary Activity of the Church), December 7, 1965.

Dignitatis Humanae (Declaration on Religious Freedom), December 7, 1965.

Gaudium et Spes (Pastoral Constitution on the Church in the Modern World), December 7, 1965.

\section{Published Primary Sources}

Balthasar, Hans Urs von. The Theology of Henri de Lubac. San Francisco: Ignatius Press, 1992.

Boersma, Hans. Nouvelle Théologie \& Sacramental Ontology: A Return to Mystery. Oxford: Oxford University Press, 2009.

Doyle, Dennis M. "Henri de Lubac and the Roots of Communion Ecclesiology." Theological Studies 60, no. 2 (1999): 209-227.

Flipper, Joseph S. Between Apocalypse and Eschaton: History and Eternity in Henri de Lubac. Minneapolis, MN: Fortress Press, 2015.

. "Henri de Lubac and Political Theology." In T\&T Clark Companion to Henri de Lubac, edited by Jordan Hillebert, 419-444. New York: Bloomsbury T\&T Clark, 2017.

. "Sacrament and Eschatological Fulfillment in Henri de Lubac's Theology of History." PhD diss., Marquette University, 2012.

Gardner, Patrick X. "An Inhuman Humanism." In T\&T Clark Companion to Henri de Lubac, edited by Jordan Hillebert, 225-246. New York: Bloomsbury T\&T Clark, 2017.

. "Modern Pentecost: Henri de Lubac on Atheism and the Spiritual Posterity of Joachim of Fiore." PhD diss, Notre Dame, 2015.

Gutiérrez, Gustavo. A Theology of Liberation: History, Politics, and Salvation. Revised edition. Translated by Sister Caridad Inda and John Eagleson. Maryknoll, NY: Orbis, 1988. 
Hillebert, Jordan. Henri de Lubac and the Drama of Human Existence. Notre Dame, IN: Notre Dame, 2021.

Komonchak, Joseph. "Theology and Culture at Mid-Century: The Example of Henri de Lubac" Theological Studies 51 (1990): 579-602.

. "Returning from Exile: Catholic Theology in the 1930s." In The Twentieth Century: A Theological Overview, edited by Gregory Baum, 35-48. New York: Orbis, 1991.

Lennan, Richard. The Ecclesiology of Karl Rahner. Oxford: Oxford University Press, 1995.

de Lubac, Henri. "L'Antisemitisme et la Conscience Chrétienne." Cahiers du Témoignage chrétien, VIVII (April-May 1942), reprinted in Résistance chrétienne au nazisme. Edited by Renée Bédarida and Jacques Prévotat (Paris: Cerf, 2006).

. "Apologetics and Theology." Republished in Theological Fragments, translated by Rebecca Howell Balinski, 91-108. San Francisco: Ignatius, 1989.

. "The Authority of the Church in Temporal Matters." Republished in Theological Fragments, translated by Rebecca Howell Balinski, 199-234. San Francisco: Ignatius Press, 1989.

. A Brief Catechesis on Nature and Grace [Petite catéchèse sur nature et grâce]. Translated by Richard Arnandez. San Francisco: Ignatius, 1984 [1980].

. Catholicism: Christ and the Common Destiny of Man [Catholicisme: les aspects sociaux du dogme]. Translated by Lancelot C. Sheppard and Elizabeth Englund. San Francisco: Ignatius, 1988.

. "Christian Explanation of our Times" ["Explication chrétienne de notre temps"]. Republished in Theology in History, translated by Anne Englund Nash, 440-456. San Francisco: Ignatius Press, 1996 [1941].

. Christian Resistance to Anti-Semitism: Memories from 1940-1944. Translated by Elizabeth Englund Nash. San Francisco: Ignatius Press, 1988.

. The Church: Paradox and Mystery [Paradoxe et Mystère de l'Église]. Translated by James R. Dunne. Staten Island, NY: Alba House, 1969.

. Corpus Mysticum: The Eucharist and the Church in the Middle Ages [Corpus Mysticum: Essai sur L'Eucharistie et l'Église au moyen âge]. Translated by Gemma Simmonds, Richard Price, and Christopher Stevens. Edited by Laurence Hemming and Susan Frank Parsons. South Bend, IN: Notre Dame, 2007 [1944].

. "The Council and the Para-Council." Appendix C in A Brief Catechesis on Nature and Grace. Translated by Richard Arnandez. San Francisco: Ignatius, 1984.

. The Drama of Atheist Humanism [Le drame de l'humanisme athée]. Translated by Edith M. Riley, Anne Englund Nash, and Mark Sebanc. San Francisco: Ignatius Press, 1995 [1944]. 
. L'Église dans la crise actuelle. Paris: Cerf, 1969.

. Entretien autour de Vatican II: Souvenirs et réflexions. Paris: France Catholique-Cerf, 1985.

. Exégèse Médiévale: Les quatre sens de l'Écriture. 4 vols. Paris: Aubier, 1959-1964.

. "L'idée chrétienne de l'homme et la recherche d'un homme nouveau," Études 255 (1947): $145-169$.

. "Letter to My Superiors." Republished in Theology in History. Translated by Anne Englund Nash. San Francisco: Ignatius Press, 1996.

. De Lubac: A Theologian Speaks. Translated by Stephen Maddux (Los Angeles: Twin Circles Publishing, 1985).

. "Memorandum on French Bishops during the Occupation of France (1940-44)." Journal of Jesuit Studies 5 (2018): 266-277.

. The Motherhood of the Church: Followed by Particular Churches in the Universal Church [La maternité de l'Église; Les églises particulières dans l'Église universelle]. Translated by Sr. Sergia Englund. San Francisco: Ignatius Press, 1982 [1971; 1971].

. Mystery of the Supernatural. Translated by Rosemary Sheed. New York: Herder and Herder, 1967.

. Pic de La Mirandole: Études et discussions. Paris: Aubier-Montaigne, 1974.

. La Postérité spirituelle de Joachim de Flore. 2 volumes. Paris: Lethielleux, 1978-1981.

La Postérité spirituelle de Joachim de Flore. Paris: Cerf, 2014.

. "The 'Sacrament of the World'?" Appendix B in A Brief Catechesis on Nature and Grace. Translated by Richard Arnandez. San Francisco: Ignatius, 1984.

. At the Service of the Church: Henri de Lubac Reflects on the Circumstances that Occasioned His Writings. Translated by Anne Elizabeth Eglund. San Francisco: Communio Books, 1993.

. The Splendor of the Church [Méditation sur l'Église]. Translated by Michael Mason. San Francisco: Ignatius Press, 1986 [1953].

. "Teilhard and the Problems of Today [Teilhard et notre temps]." In The Eternal Feminine: A Study on the Text of Teilhard de Chardin, translated by René Hague, 133-257. New York: Harper and Row, 1972 [1968].

. "The Theological Foundation of the Missions." Republished in Theology in History, translated by Anne Englund Nash, 367-427. San Francisco: Ignatius Press, 1996. 
. Vatican Council Notebooks. Volume 2. Translated by Anne Englund Nash. San Francisco: Ignatius, 2016.

McPartlan, Paul. The Eucharist Makes the Church: Henri de Lubac and John Zizioulas in Dialogue. Fairfax, VA: Eastern Christian Publications, 2006.

Milbank, John. The Suspended Middle: Henri de Lubac and the Renewed Split in Modern Catholic Theology. 2nd edition. Grand Rapids, MI: Eerdmans, 2014.

. Theology and Social Theory: Beyond Secular Reason. Oxford: Blackwell, 1990.

Murphy, Francesca A. "De Lubac, Grace, Politics and Paradox." Studies in Christian Ethics 23, no. 4 (2010): 415-430.

Nickoloff, James B. "The Church and Human Liberation: The Ecclesiology of Gustavo Gutiérrez." Phd diss., Graduate Theological Union, 1988.

O’Regan, Cyril. “A Theology of History.” In T\&T Clark Companion to Henri de Lubac, edited by Jordan Hillebert, 289-306. New York: Bloomsbury T\&T Clark, 2017.

Ratzinger, Joseph Cardinal. Principles of Catholic Theology. Translated by Sister Mary Frances McCarthy, S. N. D. San Francisco: Ignatius Press, 1982.

Riches, Aaron. "Henri de Lubac and the Second Vatican Council." In T\&T Clark Companion to Henri de Lubac, edited by Jordan Hillebert, 121-158. New York: Bloomsbury T\&T Clark, 2017.

Simmonds, Gemma. "The Mystical Body: Ecclesiology and Sacramental Theology." In T\&T Clark Companion to Henri de Lubac, edited by Jordan Hillebert, 159-180. New York: Bloomsbury T\&T Clark, 2017.

Walsh, Christopher J. "De Lubac's Critique of the Postconciliar Church,” Communio 19 (Fall 1992): 404432.

. "Henri de Lubac and the Ecclesiology of the Postconciliar Church: An Analysis of His Later Writings (1965-1991).” PhD diss., CUA, 1993.

Wood, James R. "Leaven without Loss: Church and World across Balthasar's Corpus." Pro Ecclesia: A Journal of Catholic and Evangelical Theology 29, no. 3 (2020): 308-335.

Wood, Susan K. "The Church as the Social Embodiment of Grace in the Ecclesiology of Henri de Lubac." PhD diss., Marquette University, 1986.

- "Henri de Lubac and the Church-World Relationship in Gaudium et Spes." In The Legacy of Vatican II, edited by Massimo Faggioli and Andrea Vicini, 226-247. New York: Paulist Press, 2015. 
. "The Nature-Grace Problematic within Henri de Lubac's Christological Paradox." Communio 19 (Fall 1992): 389-403. 